\title{
Synthesis and proteolytic degradation of nitrogenase in cultures of the unicellular cyanobacterium Gloeothece strain ATCC 27152
}

\author{
John P. H. Reade, ${ }^{1,2}+$ Lisa J. Dougherty, ${ }^{1}$ Lyndon J. Rogers ${ }^{2}$ \\ and John R. Gallon' \\ Author for correspondence: John R. Gallon. Tel: +44 1792295376 . Fax: +44 1792295447. \\ e-mail: j.r.gallon@swansea.ac.uk
}

1 Biochemistry Research Group, School of Biological Sciences, University of Wales Swansea, Swansea SA2 8PP, UK

2 Institute of Biological Sciences, University College of Wales, Sir George Stapledon Building, Aberystwyth SY23 3DD, UK
In cultures of the unicellular cyanobacterium Gloeothece sp. ATCC 27152 growing under alternating $12 \mathrm{~h}$ light and $12 \mathrm{~h}$ darkness, nitrogenase activity appears as cultures enter the dark phase. Synthesis of both component proteins of nitrogenase commences immediately prior to the appearance of activity and continues until about $8 \mathrm{~h}$ into the period of darkness. The two components (Fe-protein and MoFe-protein) are synthesized in a molar ratio of about 3:1. Degradation of the nitrogenase proteins starts as early as $4 \mathrm{~h}$ into the dark period and increases markedly as cultures enter the light phase. As a result, both nitrogenase proteins are completely absent from cultures during most of the light phase. In contrast, all of the other proteins investigated appeared to be present throughout the cycle of alternating light and darkness. Degradation of nitrogenase depends upon protein synthesis during the last $6 \mathrm{~h}$ of darkness and is prevented by addition of protease inhibitors. Two proteins, of $M_{r} 47000$ and 29000 , are specifically synthesized during this period and it is possible that they have a role in nitrogenase degradation. Proteolytic activity of extracts of Gloeothece, measured as the ability to degrade azocasein, increased markedly during the early part of the light period, but this increase did not depend on protein synthesis. This activity does not therefore correspond to that specifically involved in nitrogenase catabolism, though it may act on initial breakdown products generated by a nitrogenase-specific degradative system. A phycobiliprotein appears to act as a temporary store of the degradation products of nitrogenase.

Keywords: nitrogenase synthesis and degradation, unicellular cyanobacteria, Gloeothece, $\mathrm{N}_{2}$ fixation, proteolytic enzymes

\section{INTRODUCTION}

Gloeothece is a unicellular cyanobacterium that can fix $\mathrm{N}_{2}$ in air despite the fact that $\mathrm{O}_{2}$ is a potent inhibitor of nitrogenase (Fay, 1992; Gallon, 1992). Moreover, like

†Present address: Crop and Environmental Research Centre, Harper Adams University College, Newport, Shropshire TF10 8NB, UK.

Abbreviations: DRAG, dinitrogenase reductase-activating glycohydrolase; DRAT, dinitrogenase reductase ADP-ribosyl transferase; Rubisco, ribulose-1,5-bisphosphate carboxylase/oxygenase. other cyanobacteria, Gloeothece generates $\mathrm{O}_{2}$ as a result of its photosynthetic activity. When grown in air under alternating $12 \mathrm{~h}$ light and $12 \mathrm{~h}$ darkness, batch cultures of Gloeothece fix $\mathrm{N}_{2}$ only during the dark period, thereby effecting a temporal separation between oxygenic photosynthesis and $\mathrm{N}_{2}$ fixation (Gallon, 1981). This behaviour reflects the appearance and disappearance of the Fe-protein of nitrogenase (Du \& Gallon, 1993).

The temporal separation of photosynthesis and $\mathrm{N}_{2}$ fixation is found in many other non-heterocystous cyanobacteria (reviewed by Bergman et al., 1997). In 
contrast, heterocystous cyanobacteria grown under alternating light and darkness fix $\mathrm{N}_{2}$ either during the period of illumination or both in the light and in the dark (Khamees et al., 1987; Mullineaux et al., 1981). In these organisms, oxygenic photosynthesis (in vegetative cells) and $\mathrm{N}_{2}$ fixation (in heterocysts) are spatially separated.

Among cyanobacteria, fluctuations in nitrogenase activity are not always reflected in the appearance and disappearance of the Fe-protein of nitrogenase. Though this is the case in Gloeothece (Du \& Gallon, 1993) and in another unicellular cyanobacterium Cyanotbece, formerly called Synechococcus (Campbell et al., 1994; Chow \& Tabita, 1994; Colón-López et al., 1997), the filamentous non-heterocystous cyanobacterium Oscillatoria limosa behaves differently. In this organism, the Fe-protein can be detected more or less throughout a diurnal illumination cycle but a putatively inactive form predominates during the light period, when no nitrogenase activity can be detected, and is converted to an assumed active form prior to the appearance of activity (Villbrandt et al., 1992). A similar correlation between the onset of $\mathrm{N}_{2}$ fixation and the appearance of an assumed active form of the Fe-protein exists in the unusual non-heterocystous cyanobacterium Trichodesmium (Chen et al., 1998; Ohki et al., 1992; Zehr et al., 1993), which fixes $\mathrm{N}_{2}$ during the day, and in the heterocystous cyanobacterium Anabaena variabilis (Ernst et al., 1990).

Active nitrogenase has a second component, the MoFeprotein. However, in O. limosa and Trichodesmium, the $\mathrm{MoFe}$-protein of nitrogenase can be detected throughout a cycle of alternating light and darkness, though the intracellular concentration of this protein is generally greater during the period of $\mathrm{N}_{2}$ fixation (Villbrandt et al., 1992; Zehr et al., 1993). The lack of nitrogenase activity during a specific phase of the illumination cycle therefore appears to be exerted predominantly by disappearance or inactivation of the Fe-protein. In contrast, in Cyanothece, the MoFe-protein disappears from cultures during the light phase of a cycle of alternating light and darkness (Colón-López et al., 1997). In Gloeothece, synthesis of the MoFe-protein occurs only during the latter part of the light period and the first half of the dark period (Gallon et al., 1988), but it is not known whether this protein persists in cells during the period in which no nitrogenase activity can be detected.

Protein turnover reflects a balance between two components: synthesis and degradation. In Gloeothece, synthesis of one of the components of nitrogenase, the MoFe-protein, has already been studied (Gallon et al., 1988; Maryan et al., 1986). However, there have been no parallel studies on the synthesis of the Fe-protein, though it is known that this protein appears in cultures towards the end of the light phase of a cycle of alternating $12 \mathrm{~h}$ light and $12 \mathrm{~h}$ darkness (Du \& Gallon, 1993). Although the disappearance of the Fe-protein at the end of the dark phase (Du \& Gallon, 1993) implies that it is degraded, nothing is known about the nature of this process. We have, for example, found endopeptidase and aminopeptidase activities in extracts of Gloeothece (F. W. Wagner, D. L. Gleaves \& J. R. Gallon, unpublished observations), but these have not specifically been linked to turnover of nitrogenase.

Studies on the degradation of radiolabelled nitrogenase and measurements of proteolytic activity have therefore been undertaken in cultures of Gloeothece growing under alternating $12 \mathrm{~h}$ light and $12 \mathrm{~h}$ darkness to investigate whether the decline in $\mathrm{N}_{2}$ fixation that occurs in this organism towards the end of the dark period can be explained in terms of nitrogenase degradation.

\section{METHODS}

Growth of cultures. A capsule-free strain of Gloeothece sp. (Du \& Gallon, 1993) derived from strain ATCC 27152, was grown at $25^{\circ} \mathrm{C}$ in 151 batch cultures in modified ASM-1 medium (Gallon et al., 1978). Cultures were bubbled with air at $0.31 \mathrm{~min}^{-1}$ (1 culture $)^{-1}$ and illumination was provided as an alternating cycle of $12 \mathrm{~h}$ light $\left(30 \mu \mathrm{mol}\right.$ photons $\mathrm{m}^{-2} \mathrm{~s}^{-1}$ over the waveband $400-700 \mathrm{~nm}$ ) and $12 \mathrm{~h}$ darkness. Experiments were performed during the phase of exponential growth, 6-10 d after inoculation.

$\mathbf{N}_{2}$ fixation. Nitrogenase (EC 1.18.6.1) activity was measured using the acetylene reduction technique as described by Gallon et al. (1993).

Synthesis and degradation of nitrogenase. Nitrogenase synthesis was measured as incorporation of radioactivity into the enzyme from $\mathrm{Na}_{2}{ }^{35} \mathrm{SO}_{4}$ (Gallon et al., 1988; Maryan et al., 1986). A sample $(100 \mathrm{ml})$ was removed from the stock culture, centrifuged at $7000 \mathrm{~g}$ for $10 \mathrm{~min}$ and resuspended in $100 \mathrm{ml}$ of ASM-1 medium (Gallon et al., 1978) lacking $\mathrm{MgSO}_{4}$. Then, $\mathrm{Na}_{2}{ }^{35} \mathrm{SO}_{4}$ (3.7 MBq; Amersham) was added and the sample incubated for $4 \mathrm{~h}$ at $25^{\circ} \mathrm{C}$ under identical conditions of illumination to those prevailing in the stock culture. At the end of the incubation period, proteins were extracted as described by Du \& Gallon (1993) except that, instead of using the French press, cells were broken by sonication for $5 \mathrm{~min}$ (given as $30 \mathrm{~s}$ bursts separated by $2 \mathrm{~min}$ ) at $0^{\circ} \mathrm{C}$.

Degradation of nitrogenase was measured by sampling 81 of the stock culture at the beginning of the dark period. After centrifugation at $7000 \mathrm{~g}$ for $10 \mathrm{~min}$, the cells from this sample

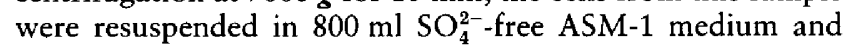
incubated in the dark for $4 \mathrm{~h}$ at $25^{\circ} \mathrm{C}$ with $29 \cdot 6 \mathrm{MBq}$ $\mathrm{Na}_{2}{ }^{35} \mathrm{SO}_{4}$. During this period, ${ }^{35} \mathrm{~S}$ was incorporated into the nitrogenase proteins. The sample was then centrifuged at $7000 \mathrm{~g}$ for $10 \mathrm{~min}$ and the radiolabelled cells resuspended in 81 complete ASM-1 lacking radioisotope. This culture was then incubated at $25^{\circ} \mathrm{C}$ under illumination identical to that received by the stock culture. Samples (1l) were removed every $4 \mathrm{~h}$ and proteins extracted as described by $\mathrm{Du} \&$ Gallon (1993), except that cell breakage was accomplished by $5 \mathrm{~min}$ sonication ( $30 \mathrm{~s}$ bursts separated by $2 \mathrm{~min}$ ) at $0^{\circ} \mathrm{C}$. Total radioactivity in $10 \mu \mathrm{l}$ of the broken cell preparation was then estimated by scintillation counting using a ${ }^{14} \mathrm{C}$ internal standard. 
SDSPAGE. Samples from a single experiment, each containing an identical amount of protein (normally about $25 \mu \mathrm{g}$ ), were applied to the wells of a $10 \%(\mathrm{w} / \mathrm{v})$ polyacrylamide gel overlaid with a $5 \%(\mathrm{w} / \mathrm{v})$ stacking gel. Electrophoresis was carried out at $200 \mathrm{~V}$ in a Bio-Rad Mini-PROTEAN II electrophoresis system until the bromophenol blue had migrated to the bottom of the gel.

Autoradiography. After SDS-PAGE, the gel was placed on a section of Whatman $3 \mathrm{MM}$ chromatography paper cut to the same size as the gel and dried under vacuum for $35 \mathrm{~min}$ at $80^{\circ} \mathrm{C}$ in a Bio-Rad model $224 \mathrm{Gel}$ Drier. The dried gel was incubated in the dark with Hyper film $\beta$-max (Amersham) for $72 \mathrm{~h}$ at $-72{ }^{\circ} \mathrm{C}$. The film was then developed and fixed. A mixture of ${ }^{14} \mathrm{C}$-labelled proteins, subjected to SDS-PAGE in parallel with the experimental samples, served to estimate the $M_{\mathrm{r}}$ values of radioactive proteins in the Gloeothece extracts.

Western blot analysis. After separation by SDS-PAGE, proteins were transferred to nitrocellulose membrane using a Bio-Rad Mini Trans-Blot Cell. Proteins were visualized by immunospecific Western blotting as described by Stal \& Bergman (1990), using polyclonal antisera raised to the following proteins: the MoFe-protein and the Fe-protein of nitrogenase, dinitrogenase reductase-activating glycohydrolase (DRAG) and dinitrogenase reductase ADP-ribosyl transferase (DRAT) from Rhodospirillum rubrum (all obtained from Dr P. Ludden, University of Wisconsin, Madison, WI, USA), the large subunit of ribulose-1,5-bisphosphate carboxylase/oxygenase (Rubisco) from Synechococcus strain PCC 7942 (Dr S. Gutteridge, DuPont Central Research and Development, DE, USA) and C-phycoerythrin from Phormidium persicinum (Dr R. MacColl, New York State Department of Health, NY, USA). The $M_{\mathrm{r}}$ values of these proteins were estimated from the behaviour of a mixture of proteins of known $M_{\mathrm{r}}(106000,80000,49500,32500,27500$ and 18500) subjected to SDS-PAGE in parallel with the Gloeothece extracts and visualized on the nitrocellulose membranes by staining with $0.1 \%(\mathrm{w} / \mathrm{v})$ Ponceau $\mathrm{S}$ in $0.17 \mathrm{M}$ acetic acid.

Proteolytic activity. Proteolytic activity was measured with azocasein as a substrate, using a modification of the method of Plantner (1991). A sample of culture (2l) was harvested by centrifugation at $7000 \mathrm{~g}$ for $15 \mathrm{~min}$. The pelleted cells were resuspended in $2 \mathrm{ml} 50 \mathrm{mM}$ phosphate buffer, $\mathrm{pH} 7.4$ and broken by 5 min sonication ( $30 \mathrm{~s}$ bursts separated by $2 \mathrm{~min}$ ) at $0{ }^{\circ} \mathrm{C}$. To $0.45 \mathrm{ml}$ of this broken-cell extract was added $0.75 \mathrm{ml}$ azocasein (10 $\mathrm{mg} \mathrm{m}^{-1}$ in sodium phosphate buffer). After incubation at $30^{\circ} \mathrm{C}$ for $1 \mathrm{~h}$, the reaction was terminated by addition of $0.175 \mathrm{ml} 10 \%(\mathrm{w} / \mathrm{v})$ trichloroacetic acid. The reaction mixture was then centrifuged at $3000 \mathrm{~g}$, after which $0.8 \mathrm{ml}$ of the supernatant was added to $60 \mu 10 \mathrm{M} \mathrm{NaOH}$. The absorbance of this solution was then measured at $440 \mathrm{~nm}$ against a zero-time blank. One unit of proteolytic activity is defined as catalysing the liberation of sufficient trichloroaceticacid-soluble material to give an increase in $A_{440}$ of 1 after incubation for $1 \mathrm{~h}$ at $30^{\circ} \mathrm{C}$. A control incubation, in which broken-cell extract was substituted by $0.45 \mathrm{ml}$ phosphate buffer, demonstrated that non-enzymic breakdown of azocasein was insignificant.

Measurement of protein. The protein content of extracts of Gloeothece was measured as described by Bailey (1962). In the case of samples subjected to SDS-PAGE (Du \& Gallon, 1993), $10 \mu \mathrm{l}$ of sample was withdrawn for measurement of protein
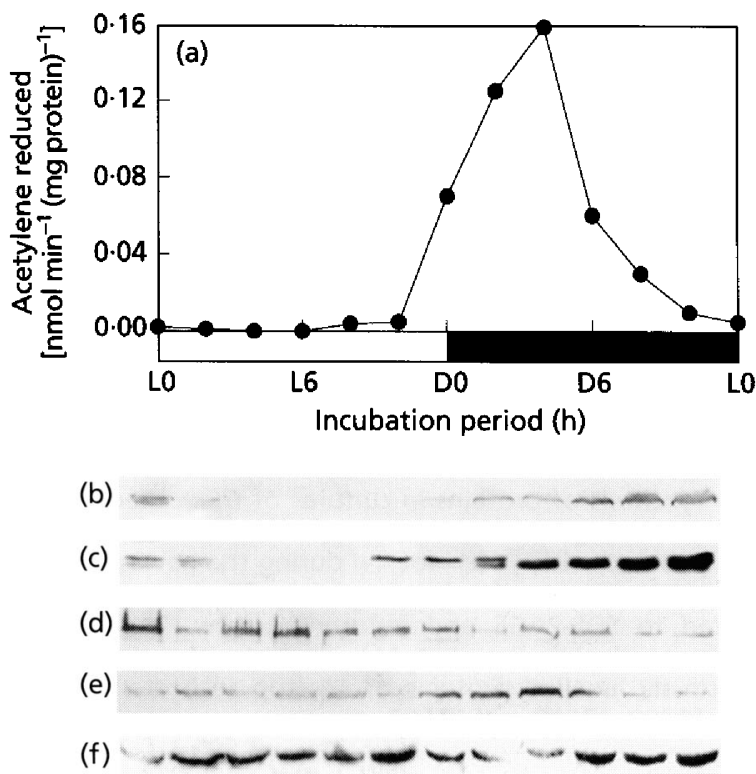

(g)

Fig. 1. Nitrogenase activity and the intracellular concentrations of various proteins in cultures of Gloeothece sp. ATCC 27152 growing under alternating $12 \mathrm{~h}$ light $(\mathrm{L})$ and $12 \mathrm{~h}$ darkness (D). Nitrogenase activity (a) was measured as acetylene reduction during the $60 \mathrm{~min}$ period following the sampling time indicated. Intracellular proteins are shown as immunospecific Western blots after SDS-PAGE of extracts of Gloeothece, developed using antiserum to (b) the MoFe-protein of nitrogenase, (c) the Fe-protein of nitrogenase, (d) DRAT, (e) DRAG, $(f)$ the large subunit of Rubisco or (g) C-phycoerythrin.

prior to addition of 2-mercaptoethanol and bromophenol blue, which interfere with the assay.

\section{RESULTS}

\section{Turnover of nitrogenase and other proteins in Gloeothece}

Batch cultures of Gloeothece grown under alternating $12 \mathrm{~h}$ light $\left(30 \mu \mathrm{mol} \mathrm{m}^{-2} \mathrm{~s}^{-1}\right)$ and $12 \mathrm{~h}$ darkness showed patterns of nitrogenase activity similar to those reported previously (Du \& Gallon, 1993; Gallon et al., 1988), with $\mathrm{N}_{2}$ fixation confined almost entirely to the dark period (Fig. 1a). $\mathrm{N}_{2}$ fixation was maximal $4-6 \mathrm{~h}$ into the dark (D4-6). (The shorthand notation adopted here uses the prefix ' $L$ ' to refer to measurements made, or samples taken, during the light phase, and ' $D$ ' to refer to measurements made during the period of darkness. Thus D1 refers to the situation in a culture $1 \mathrm{~h}$ after the onset of darkness, whilst $\mathrm{L} 2$ applies to a culture $2 \mathrm{~h}$ into the light phase. Cultures enter the light phase at L0 and enter the dark phase at D0.)

The MoFe-protein of nitrogenase $\left(M_{r} 60300\right)$ could be detected immunologically throughout the dark period (Fig. 1b) but rapidly disappeared once illumination commenced and did not reappear until cultures entered 


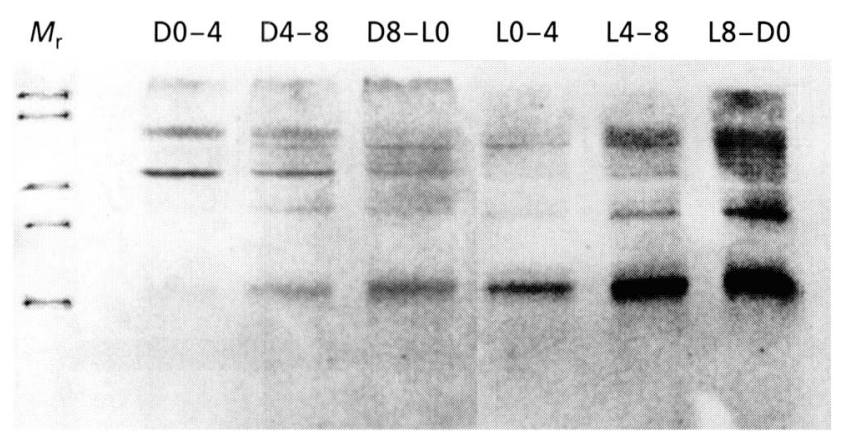

Fig. 2. Synthesis of proteins in cultures of Gloeothece growing under alternating $12 \mathrm{~h}$ light $(\mathrm{L})$ and $12 \mathrm{~h}$ darkness (D). Cultures were incubated with ${ }^{35} \mathrm{SO}_{4}^{2-}$ for $4 \mathrm{~h}$ during the period indicated, after which extracts (each containing $25 \mu \mathrm{g}$ protein) were subjected to SDS-PAGE and autoradiography. The bands on the left hand side (headed $M_{r}$ ) illustrate the mobilities of radioactively labelled proteins of $M_{r}$ (top to bottom) 106000 , $80000,32500,27500$ and 18500 .

the following dark phase. The Fe-protein of nitrogenase $\left(M_{\mathrm{r}} 38500\right.$ and 40000$)$ behaved similarly (Fig. 1c), though this protein could be detected earlier than the MoFe-protein, at L10 rather than at D0, and persisted rather longer into the following light period. This behaviour was consistent with that reported previously for the Fe-protein (Du \& Gallon, 1993). The larger, 'modified' (Du \& Gallon, 1993) form of the Fe-protein appeared first (as the upper band in Fig. 1c), but disappeared by about D4. Thereafter, the smaller form of the Fe-protein (lower band) predominated, though the larger form reappeared as cultures entered the light phase.

Unlike the protein components of nitrogenase (Fig. 1b, c), all of the other proteins investigated could be detected throughout the period of alternating light and darkness (Fig. 1d-g). DRAT and DRAG are enzymes responsible for the reversible modification of the Fe-protein of nitrogenase from $R$. rubrum (Ludden et al., 1988) and other bacteria. Antigenically similar proteins have been reported in Gloeothece (Du et al., 1994), though there is no evidence that these proteins act on nitrogenase in this organism. Antiserum to DRAT reacted with two proteins in extracts of Gloeothece subjected to SDS-PAGE. A strong reaction was seen with a protein of $M_{r} 69000$ and a weaker reaction with a protein of $M_{\mathrm{r}} 60000$ (Fig. 1d). A single protein, of $M_{\mathrm{r}} 63000$, reacted with antiserum to DRAG (Fig. 1e). Antiserum to the large subunit of Rubisco, the enzyme that catalyses photosynthetic $\mathrm{CO}_{2}$ fixation in plants and cyanobacteria, reacted with a single protein of $M_{r} 50000$ in extracts of Gloeothece (Fig. 1f). Two proteins, of $M_{\mathrm{r}} 20000$ and 17000 , reacted though only weakly, with antiserum raised against the accessory photosynthetic pigment $\mathrm{C}$ phycoerythrin (Fig. 1g). These corresponded, respectively, to the $\beta$ and $\alpha$ subunits of this protein (Mazel et al., 1986; Rümbeli et al., 1987). Spectroscopic analysis of the phycobiliprotein pigments showed that their overall

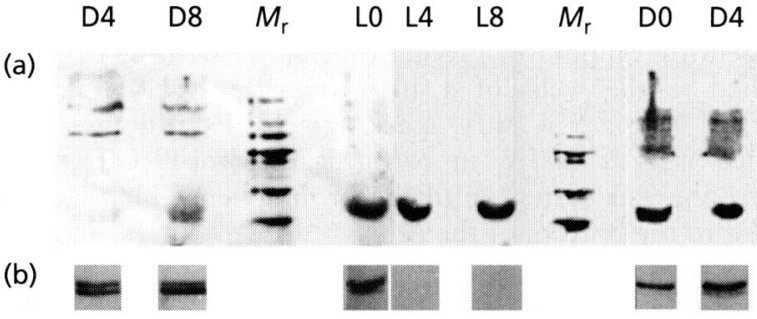

Fig. 3. Degradation of radiolabelled proteins in cultures of Gloeothece growing under alternating $12 \mathrm{~h}$ light $(L)$ and $12 \mathrm{~h}$ darkness (D). Cultures were incubated with ${ }^{35} \mathrm{SO}_{4}^{2-}$ during the first $4 \mathrm{~h}$ of darkness (D0-D4), after which the radioactive substrate was removed. Samples were removed at D4 and at subsequent $4 \mathrm{~h}$ intervals as shown at the head of each gel track. Extracts were then subjected to SDS-PAGE and autoradiography (a). The tracks headed $M_{\mathrm{r}}$ show the mobilities of radioactively labelled proteins of $M_{\mathrm{r}}$ (top to bottom) 66000, 45000,36000, $29000,23000,20000$ and 14000 . For comparative purposes (b), a Western blot showing the Fe-protein of nitrogenase in each sample is shown below the corresponding gel track.

intracellular concentration did not fluctuate substantially during growth of Gloeothece under alternating light and darkness, though the concentrations of phycoerythrin were lowest during the early part of the dark phase (data not shown).

\section{Protein synthesis}

As revealed by autoradiography of SDS-PAGE gels (Fig. 2), radioactivity from ${ }^{35} \mathrm{SO}_{4}^{2-}$ was incorporated predominantly into three proteins during the first $4 \mathrm{~h}$ of the dark period (D0-4). These proteins had $M_{\mathrm{r}}$ values of 60000 , 39000 and 20000, respectively. During the period D4-8, incorporation of radioactivity into the two larger proteins appeared to be slightly less than during D0-4, whilst that into the smallest protein was greater. In addition, radioactivity was now observed in proteins of $M_{\mathrm{r}} 47000$ and 29000 . During the final $4 \mathrm{~h}$ of darkness (D8-L0), incorporation of radioactivity into the protein of $M_{\mathrm{r}} 39000$ had markedly declined whilst virtually no incorporation into the protein of $M_{r} 60000$ was observed. Significant radioactivity was incorporated into the proteins of $M_{r} 47000,29000$ and 20000 . For the first $4 \mathrm{~h}$ after cultures entered the light period (LO-L4) incorporation of radioactivity from ${ }^{35} \mathrm{SO}_{4}^{2-}$ was largely confined to the protein of $M_{\mathrm{r}} 20000$, though some incorporation into the proteins of $M_{\mathrm{r}} 47000$ and 29000 continued. Thereafter, however, many proteins became radioactively labelled.

Densitometry scans of the autoradiographs of the SDSPAGE gels showed that, during the period $\mathrm{D} 0-4,34 \%$ of the total radioactivity incorporated into protein was found in the protein of $M_{\mathrm{r}} 60000$ whilst $37 \%$ was found in the protein of $M_{\mathrm{r}} 39000$. Most of the remaining radioactivity $(20 \%)$ was found in the protein of $M_{\mathrm{r}}$ 20000 . These figures were confirmed by scintillation counting of appropriate gel slices. 


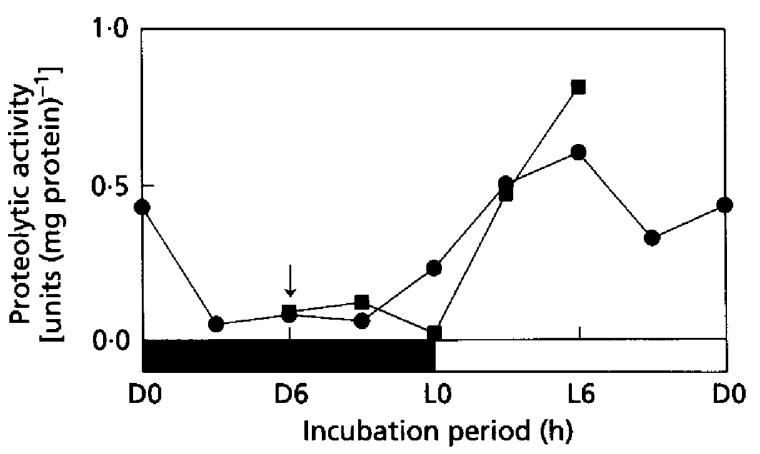

Fig. 4. Degradation of azocasein by extracts prepared from cultures of Gloeothece growing under alternating $12 \mathrm{~h}$ light (L) and $12 \mathrm{~h}$ darkness (D). At D6 $(6 \mathrm{~h}$ into the dark period; see arrow), $0.1 \mathrm{mg}$ chloramphenicol $\mathrm{ml}^{-1}$ was added to one culture (a). The control culture (C) received no chloramphenicol.

\section{Protein degradation}

The proteins of $M_{\mathrm{r}} 60000$ and 39000 , radioactively labelled during the first $4 \mathrm{~h}$ of darkness, had almost completely disappeared by the start of the following light period at L0 (Fig. 3a). Densitometry of autoradiographs suggested that breakdown of these proteins started between D4 and D8. In contrast, as radioactivity in these proteins steadily declined during the last $8 \mathrm{~h}$ of darkness and for $4 \mathrm{~h}$ into the succeeding light period, it accumulated in a protein of $M_{\mathrm{r}} 17000$ (compare D4, D8, L0 and L4). After L8, radioactivity also appeared in a number of other proteins.

\section{Proteolytic activity in Gloeothece}

In cultures of Gloeothece grown under alternating light and darkness, proteolytic activity, measured as the ability of extracts to degrade the artificial substrate azocasein, varied between 0.046 and 0.616 units (mg protein $)^{-1}$. Activity was very low between D3 and D9 but thereafter increased, reaching a maximum between L3 and L6 (Fig. 4).

Addition of $0 \cdot 1 \mathrm{mg}$ chloramphenicol $\mathrm{ml}^{-1}$ to cultures of Gloeothece at D6 completely abolished protein synthesis by D8 (data not shown). It has previously been shown that this treatment markedly decreased the decline in nitrogenase activity normally seen during the last $6 \mathrm{~h}$ of the dark phase and also allowed immunologically identifiable Fe-protein of nitrogenase to persist well into the following light phase (Du \& Gallon, 1996). Addition of chloramphenicol at D6 did not, however, prevent the subsequent increase in the ability of extracts of Gloeothece to degrade azocasein (Fig. 4).

Addition of $1 \mu \mathrm{M}$ pepstatin $\mathrm{A}$, an inhibitor of aspartic proteases, at D6 had no more than a slight stimulatory effect on nitrogenase activity during the remainder of the dark phase and did not allow activity to extend into the following light period (Fig. 5a). Nevertheless, degradation of the Fe-protein was markedly decreased fol-

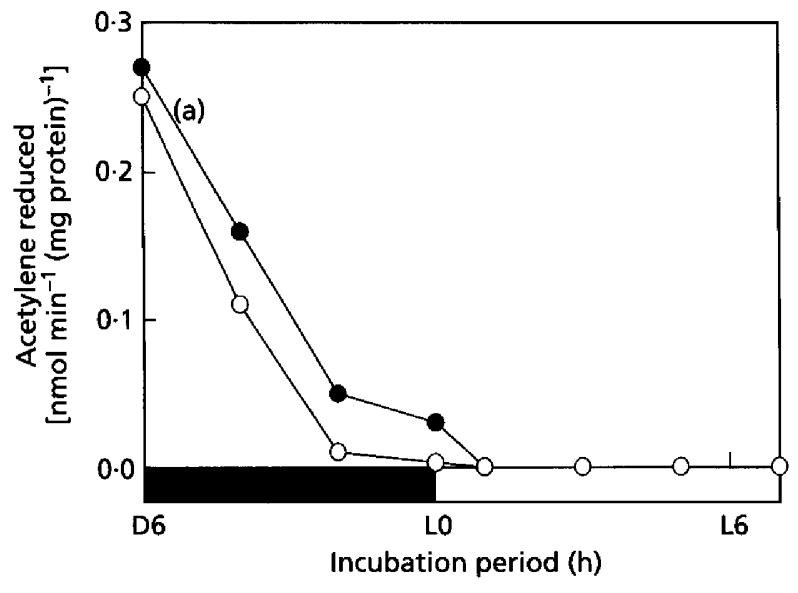

(b)

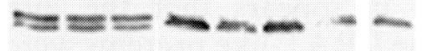

Fig. 5. The effect of $1 \mu \mathrm{M}$ pepstatin $\mathrm{A}$ on nitrogenase activity (a) and synthesis of the Fe-protein of nitrogenase (b) in cultures of Gloeothece growing under alternating light (L) and darkness (D). Acetylene reduction for the period D6-L7 (a) is shown in the presence $(O)$ and absence $(O)$ of $1 \mu \mathrm{M}$ pepstatin $A$, added at D6. The presence of the Fe-protein in Western blots after SDS-PAGE of extracts of cultures receiving pepstatin $A$ is shown for each sample point (b). In the absence of pepstatin $A$, the Feprotein in cultures of Gloeothece behaved as shown in Fig. 1(c).

lowing addition of pepstatin A (compare Fig. $5 \mathrm{~b}$ with Fig. 1c). In the presence of pepstatin A, immunologically detectable Fe-protein persisted in cells of Gloeothece until at least $\mathrm{L} 7$.

Similar effects were seen following addition of other inhibitors of proteolysis at D6. These included $1 \mu \mathrm{M}$ PMSF or 4-(2-aminoethyl)-benzenesulphonyl fluoride (AEBSF), both inhibitors of serine proteases, and $1 \mathrm{mM}$ $\mathrm{Na}_{2}$ EDTA, which inhibits metalloproteases. In this last case, the inhibitor was added in the presence or absence of $5 \mathrm{mM} \mathrm{CaCl}_{2}$, which prevents the EDTA-mediated inhibition of nitrogenase activity in Gloeothece (Gallon \& Hamadi, 1984; Hamadi \& Gallon, 1981). Except when EDTA was added alone (in which case no activity was seen), these additions had little effect on nitrogenase activity, which had usually completely disappeared by L1. However, in every case, degradation of the Feprotein was markedly decreased so that the protein remained detectable in cell extracts until at least L5. In contrast to these findings, addition of $10 \mu \mathrm{M}$ leupeptin, an inhibitor of thiol proteases, did not prevent nitrogenase degradation when added at D6. This may indicate that thiol proteases are not involved in nitrogenase breakdown though it is also possible that leupeptin, which at neutral $\mathrm{pH}$ carries a positive charge, may not penetrate the cells of Gloeothece very effectively. 


\section{DISCUSSION}

As reported previously (Du \& Gallon, 1993; Gallon $e t$ al., 1988), the appearance of the Fe-protein of nitrogenase at L10 (Fig. 1c) is closely followed by detectable nitrogenase activity (Fig. 1a) in cultures of Gloeothece growing under alternating light and darkness. Although the Western blot suggests that synthesis of the MoFeprotein, which appears at D0 (Fig. 1b), lags slightly behind that of the Fe-protein, this may simply reflect the lower sensitivity of the antiserum to this protein. It seems more likely that synthesis of the two proteins of nitrogenase is coordinately regulated in cultures of Gloeothece. On the other hand, none of the other proteins investigated showed such substantial fluctuations in intracellular concentration, so it seems that the appearance and disappearance of the protein components of nitrogenase in cultures grown under alternating light and darkness is unusual among Gloeothece proteins. Although it appears that the intracellular concentrations of the DRAT-like proteins were greatest during the period of illumination (Fig. 1d), whilst those of the DRAG-like protein were greatest during the early part of the dark period (Fig. 1e), it is not known whether the conditions of blotting allow any quantitative deductions to be made. Moreover, these fluctuations have not been consistently observed. As a consequence, no significance is ascribed to the variations seen in Fig. 1(d and e). The poor reaction between extracts of Gloeothece and antibodies raised against phycoerythrin in $P$. persicinum (Fig. $1 \mathrm{~g}$ ) may result from structural differences in this protein between the two organisms.

Maryan et al. (1986) showed that radioactivity from ${ }^{35} \mathrm{SO}_{4}^{2-}$ could be incorporated into the MoFe-protein of Gloeothece nitrogenase which appeared on SDS-PAGE as two bands of $M_{\mathrm{r}} 60000$ and 55000 representing, respectively, the $\beta$ and $\alpha$ subunits of this protein. The conditions of electrophoresis used in this study were selected to identify proteins over a wide range of $M_{r}$ values and were apparently unable to resolve these two polypeptides. This has also been observed in other systems (Kennedy et al., 1976). The radioactive band with an $M_{\mathrm{r}}$ of 60000 , (Figs 2, 3a), whose position on the gels coincides exactly with that of the MoFe-protein as determined by Western blotting, probably therefore includes both the $\alpha$ and $\beta$ subunits of the MoFe-protein. The radioactive band at $M_{\mathrm{r}} 39000$ (Figs 2, 3a) corresponded with the protein that reacted with antiserum to the Fe-protein of nitrogenase and can therefore be assigned to the Fe-protein of nitrogenase. However, the two forms visible in Western blots (Fig. 1c) could not be distinguished in the autoradiographs (Figs 2, 3a). In our experience, this is not an uncommon occurrence and probably reflects the poorer resolving power of autoradiography over that of Western blotting.

De novo synthesis of both nitrogenase proteins was largely confined to the first $8 \mathrm{~h}$ of the dark period (D0-8). This confirms the findings of Gallon et al. (1988) for the MoFe-protein and is in marked contrast to general protein synthesis, most of which takes place during the last $8 \mathrm{~h}$ of the light phase (L4-D0). The distinct period of synthesis of both nitrogenase proteins coincides with the phase of rising nitrogenase activity.

During the period of maximum synthesis of the nitrogenase proteins (D0-D4), $37 \%$ of the total radioactivity incorporated into protein was found in the band that, on SDS-PAGE, corresponded to the Fe-protein of nitrogenase, whilst $34 \%$ was found in the band that corresponded to the MoFe-protein. The amino acid sequences of the nitrogenase proteins from Gloeothece have not been determined, but sequences for the nitrogenase proteins of the similar unicellular cyanobacterium Cyanothece (Synechococcus) RF-1 (Huang \& Chow, 1988) are available from GenBank (accession no. U22146). These show that, excluding the initiating methionine residue (which is usually removed during post-translational processing), the polypeptide chain of the Fe-protein of nitrogenase contains 15 residues (cysteine or methionine) that contain sulphur. Similarly the $\alpha$ and $\beta$ polypeptide chains of the MoFe-protein of nitrogenase contain, respectively, 22 and 19 sulphurcontaining amino acid residues. Assuming that the mature polypeptide chains of the Fe-protein of Gloeothece nitrogenase (a dimer) contain 30 atoms of S per molecule whilst the polypeptide chains of the MoFeprotein (an $\alpha_{2} \beta_{2}$ tetramer) contain 82 atoms of $S$ per molecule, then the relative incorporation of radioactivity from ${ }^{35} \mathrm{SO}_{4}^{2-}$ into these proteins implies that they are synthesized in the ratio of $3 \mathrm{~mol} \mathrm{Fe}$-protein per mol MoFe-protein. This is consistent with the observation that several $\mathrm{N}_{2}$-fixing bacteria contain an excess of $\mathrm{Fe}$ protein over MoFe-protein and also implies that Gloeothece contains sufficient Fe-protein to allow the MoFe-protein to function as two catalytically independent halves, each with a binding site for Fe-protein (see, for example, Smith \& Eady, 1992).

Only one protein, of $M_{\mathrm{r}} 20000$, was identified as being synthesized throughout the diurnal illumination cycle. This protein is tentatively identified as a subunit of a phycobiliprotein, based on its $M_{r}$, which was within the range (17000-22000) reported for these proteins (Sidler, 1994). The electrophoretic behaviour of this radioactive protein also correlates well with that of a Gloeothece polypeptide that gave a weak antigenic reaction with antibodies to C-phycoerythrin (Fig. $1 \mathrm{~g}$ ) and is probably the $\beta$ subunit of that protein, as well as with a pigmented area that was easily visible in SDS-PAGE gels.

Degradation of the nitrogenase proteins starts between D4 and D8 (Fig. 3a). It should be noted, however, that synthesis of nitrogenase continues during the dark period, in parallel with this degradation. For example, by $L 0$, virtually all of the $\left[{ }^{35} S\right]$ nitrogenase that had been synthesized during the period D $0-4$ had disappeared (Fig. 3a). Nevertheless, immunologically identifiable Feprotein (Figs 3b, 1c) and MoFe-protein (Fig. 1b) could easily be detected on Western blots. Non-radioactive nitrogenase had therefore clearly been synthesized after ${ }^{35} \mathrm{SO}_{4}^{2-}$ had been removed from the culture at $\mathrm{D} 4$ and had not been completely degraded by $\mathrm{L} 0$. These findings 
imply that, for at least part of the dark period, synthesis and degradation of nitrogenase occur simultaneously in Gloeothece.

Like the protein of $M_{\mathrm{r}} 20000$ that was synthesized throughout the illumination cycle (Fig. 2), the protein of $M_{\mathrm{r}} 17000$ that accumulated as nitrogenase was being degraded (Fig. 3a) may be a subunit of a phycobiliprotein. For example, it also corresponded to a polypeptide (probably the $\alpha$ subunit) that reacted with antiserum to C-phycoerythrin. However, because of distortions that occurred when the gels were dried prior to autoradiography, it is not possible at this stage to state categorically that the protein of $M_{\mathrm{r}} 17000$ is distinct from the protein of $M_{\mathrm{r}} 20000$ that was readily labelled during incubation with ${ }^{35} \mathrm{SO}_{4}^{2-}$. Just as autoradiography did not resolve either the $\alpha$ and $\beta$ subunits of the MoFe-protein of nitrogenase or the two forms of the Fe-protein, this procedure may not be able to distinguish satisfactorily between the $\alpha$ and $\beta$ subunits of the various phycobiliproteins that are synthesized by Gloeothece. Hence, in Figs 2 and 3(a), radiolabelled phycobiliproteins appear as a diffuse smear rather than as a series of separate bands. Wyman et al. $(1985,1986)$ have proposed that phycoerythrin may act as a reserve of nitrogen in the marine unicellular cyanobacterium Synechococcus sp. WH7803 (DC2), but there is no evidence that phycobiliproteins represent a temporary store of newly fixed nitrogen in Gloeothece (Gallon et al., 1990). This does not, of course, preclude the possibility that one or more of these proteins acts as a reservoir of amino acids released by catabolism of nitrogenase, as is implied by the accumulation of radioactivity in the protein of $M_{\mathrm{r}} 17000$ as ${ }^{35} \mathrm{~S}$ disappears from nitrogenase.

Although degradation of both proteins of nitrogenase occurred during the period D8-L4, in neither case could any immunologically identifiable breakdown product be seen (Fig. 1; Du \& Gallon, 1993). This contrasts with the situation in vitro (Dougherty et al., 1996; Gallon et al., 1995) but implies that, in vivo, the initial stages of degradation are followed by a rapid and complete breakdown of nitrogenase. During the period L4-8, neither the Fe-protein nor the MoFe-protein of nitrogenase could be detected in extracts of Gloeothece. In this respect, Gloeothece resembles Cyanothece sp. strain ATCC 51142 (Colón-López et al., 1997) but differs from all of the other non-heterocystous cyanobacteria so far examined, none of which show complete turnover of nitrogenase when grown under alternating light and darkness. In all of these cyanobacteria, both the MoFeprotein and the Fe-protein of nitrogenase could be detected in cells throughout the illumination cycle (Chen et al., 1998; Ohki et al., 1992; Villbrandt et al., 1992; Zehr et al., 1993).

Degradation of nitrogenase appears to commence between D4 and D8 (Fig. 3a), but is particularly active when cells enter the light phase (Fig. 1). This degradation is dependent upon protein synthesis, since it is markedly inhibited by addition of chloramphenicol at D6 (Du \&
Gallon, 1996). It also depends upon the activity of proteolytic enzymes. The simplest explanation for these observations would be that one or more component of a nitrogenase-specific proteolytic system is synthesized during the latter stages of the dark period. The observation, reported here, that a range of protease inhibitors interfere with this degradation suggests that aspartic, serine and metalloproteases (but not necessarily thiol proteases) may all be involved in degradation of the Fe-protein, possibly acting as a cascade of closely associated enzymes. Previous work has shown that this proteolytic system shows considerable specificity towards the Gloeothece enzyme. For example, extracts that rapidly degraded the Fe-protein of Gloeothece nitrogenase were unable to degrade the equivalent protein from Klebsiella pneumoniae (Gallon et al., $1995)$, though they could degrade the Fe-protein from $R$. rubrum (L. J. Dougherty \& J. R. Gallon, unpublished observations).

During the last $8 \mathrm{~h}$ of the dark period (D4-L0) and the early part of the following light period (L0-L4), two proteins, of $M_{\mathrm{r}} 47000$ and 29000 , were specifically synthesized by cultures of Gloeothece. The appearance of these proteins coincided with the breakdown of nitrogenase, so it is tempting to speculate that they may be involved in nitrogenase catabolism. However, there is no direct evidence for this. On the other hand, the proteins of $M_{r} 47000$ and 29000 do not appear to be components of the azocasein-degrading system whose stimulation after D9 was independent of protein synthesis. Similarly, the enzymes that degrade azocasein do not correspond to the proteolytic system specifically involved in nitrogenase breakdown, since azocasein degradation was stimulated even in the presence of chloramphenicol and does not, apparently, show a high degree of substrate specificity. The azocasein-degrading enzymes may, however, catalyse the further breakdown of initial degradation products generated by one or more nitrogenase-specific protease whose synthesis commences after D6.

Even when nitrogenase degradation was prevented by, for example, addition of chloramphenicol (Du \& Gallon, 1996) or inhibitors of proteases (Fig. 5b), nitrogenase activity declined during the latter part of the dark period. Loss of activity is not, therefore, simply a consequence of nitrogenase breakdown. Rather, it appears that $\mathrm{N}_{2}$ fixation declines as a consequence of a decreased breakdown of glucan reserves that would, in turn, limit the supply of ATP and reductant for nitrogenase synthesis and activity, the supply of carbon skeletons for assimilation of newly fixed nitrogen and the rate of respiration, which declines in parallel with the fall in nitrogenase activity (Gallon, 1992; Gallon et al., 1988). Since respiratory consumption of $\mathrm{O}_{2}$ is an important mechanism by which Gloeothece limits the inhibitory effect of $\mathrm{O}_{2}$ on $\mathrm{N}_{2}$ fixation, the observed decline in glucan-supported respiration may exacerbate $\mathrm{O}_{2}$-inactivation of nitrogenase. This dependence of nitrogenase activity on glucan breakdown also explains 
why, even in untreated cultures of Gloeothece, nitrogenase activity declines after D6 despite the fact that nitrogenase proteins are present in the cells until L.2 (Fig. 1).

As well as inhibiting nitrogenase activity and, at least transiently, nitrogenase synthesis (Maryan et al., 1986), it is possible that $\mathrm{O}_{2}$ might stimulatc degradation of nitrogenase in Gloeothece. If so, nitrogenase breakdown during the latter part of the dark period could increase as a result of the decline in respiratory $\mathrm{O}_{2}$ consumption that occurs at the same time. Such an effect of $\mathrm{O}_{2}$ could also explain the rapid disappearance of nitrogenase that occurs once cultures of Gloeothece enter the light phase and commence photosynthesis (Fig. 1b, c). In support of a link between $\mathrm{O}_{2}$ and nitrogenase breakdown, extracts of Gloeothece degraded nitrogenase more rapidly when incubated in air than in the absence of $\mathrm{O}_{2}$ (Gallon et al., 1995). However, based on studies with A. variabilis and Cyanothece sp. strain A TCC 51142, it has been further suggested that $\mathrm{O}_{2}$-damaged nitrogenase is preferentially targeted for proteolysis (Colón-lópez et al., 1997; Durner et al., 1996). Though this is an attractive hypothesis, it does not appear to be the case in Gloeothece. For example, nitrogenase that had been inactivated by transient exposure to $\mathrm{O}_{2}$ was no more rapidly degraded in vitro in the absence of $\mathrm{O}_{2}$ than was active nitrogenase, which had not been exposed to $\mathrm{O}_{2}$ (Gallon et al., 1995). It therefore appears likely that the nitrogenase-specific protcolytic system in extracts of Gloeothece is stimulated directly by $\mathrm{O}_{2}$ rather than by $\mathrm{O}_{2}$-inactivation of its substrate. On the other hand, proteolytic degradation of nitrogenase in vitro was also stimulated by ATP or by the presence of reducing conditions (Dougherty et al., 1996), and it could be increases in these rather than in $\mathrm{O}_{2}$ that explain the stimulation of nitrogenase breakdown that occurs when cultures of Gloeothece enter the light period.

In cultures of a number of cyanobacteria, including unicellular strains, the diurnal pattern of $\mathrm{N}_{2}$ fixation seen under alternating light and darkness reflects an endogenous circadian rhythm. For example, this pattern persists after cultures are transferred from alternating light and darkness to constant illumination (Chen et al., 1998; Colón-López et al., 1997; Mitsui et al., 1986; Mitsui \& Suda, 1995; Stal \& Krumbein, 1985). This is not, however, the case in Gloeothece (Gallon \& Chaplin, 1988). In this cyanobacterium, the perfect diurnal pattern of $\mathrm{N}_{2}$ fixation seen under alternating light and darkness is lost following removal of the period of darkness, reverting within $24 \mathrm{~h}$ to the pattern seen in cultures maintained under constant illumination, in which peaks of nitrogenase activity are separated by about $40 \mathrm{~h}$ (Mullineaux et al., 1981). Thus, in Gloeothece, the endogenous rhythm in $\mathrm{N}_{2}$ fixation is not circadian. The diurnal pattern of $\mathrm{N}_{2}$ fixation seen under alternating $12 \mathrm{~h}$ light and $12 \mathrm{~h}$ darkness therefore appears to be imposed by the illumination regime (Gallon et al., 1988). Thus, whilst it is possible that the fluctuations in nitrogenase synthesis and degradation reported here reflect an endogenous circadian rhythm in Gloeothece, there is no evidence to support this view. The decline in nitrogenase activity, the inhibition of nitrogenase synthesis and the onset of degradation, all of which occur at around D6, coincide with a decreascd rate of glucan breakdown and an increase in the intracellular ratio of ADP to ATP (Gallon et al., 1988). This is probably a consequence of depletion of intracellular glucan reserves after several hours of darkness. The accompanying decline in respiratory activity (Gallon, 1992) would lead to an increase in intracellular $\mathrm{O}_{2}$. Singly or in combination, these factors could affect the rate of $\mathrm{N}_{2}$ fixation by acting on nitrogenase synthesis, inactivation and degradation without involving any endogenous circadian rhythm. The recommencement of nitrogenase synthesis after a period of darkness requires at least $4 \mathrm{~h}$ of illumination (Gallon et al., 1988), but there is a further lag of about $6 \mathrm{~h}$ before the nitrogenase proteins reappear. This may reflect a need to replenish reserves that have become depleted in the dark.

In Cyanothece (Synechococcus) strain BG 43511, the diurnal pattern of $\mathrm{N}_{2}$ fixation under alternating light and darkness has further been explained in terms of synchronous cell division, with nitrogenase activity confined to a specific phase in the cell cycle (Mitsui et al., 1986). This cyanobacterium has a doubling time close to $24 \mathrm{~h}$ under these conditions. In contrast, Gloeothece has a minimum doubling time of about $50 \mathrm{~h}$ when grown diazotrophically under alternating $12 \mathrm{~h}$ light and $12 \mathrm{~h}$ darkness (Gallon et al., 1988). It therefore scems most unlikely that the fluctuations in nitrogenase activity, synthesis and degradation seen in Gloeothece could be related to events regulated by the cell cycle.

\section{ACKNOWLEDGEMENTS}

We gratefully acknowledge the support of the AFRC, now BBSRC, (L:K) who funded this research and the award of an EPSRC studentship to L. J. D. We also thank Drs S. Gutteridge, P. Ludden and R. MacColl for their generous gifts of antisera.

\section{REFERENCES}

Bailey, J. L. (1962). Fstimation of protein: Folin-Ciocalteau reagcut. In Techniques in Protein Chemistry, p. 293-294. Edited by J. L. Bailey. Amsterdam: Flsevier.

Bergman, B., Gallon, J. R., Rai, A. N. \& Stal, L. J. (1997). N. fixation by non-heterocystous cyanobacteria. FEMS Microbiol Rev 19 , 13918.5 .

Campbell, C., Takeyama, H. \& Mitsui, A. (1994). Cyclic synthesis of messenger $\mathrm{RNA}$ from nitrogenase nifH gene in synchronous cultures of marine unicellular cyanobacterium, Synecbococcus sp. strain Miami BG043511. J Mar Biotechnol 2, 39-43.

Chen, Y.-B., Dominic, B., Mellon, M. T. \& Zehr, J.P. (1998). Circadian rhythm of nitrogenase gene expression in the diazotrophic filamentous nonheterocystous cyanohacterium Trichedesmitum sp. strain IMS 101. I Bacteriol 180, 3598-3605.

Chow, T. J. \& Tabita, F. R. (1994). Reciprocal light-dark transcrip- 
tional control of nif and $r b c$ expression and light-dependent posttranslational control of nitrogenase activity in Synechococcus sp. strain RF-1. J Bacteriol 176, 6281-6285.

Colón-L6́pez, M. S., Sherman, D. \& Sherman, L. A. (1997). Transcriptional and translational regulation of nitrogenase in light-dark- and continuous-light-grown cultures of the unicellular cyanobacterium Cyanothece sp. strain ATCC 51142. J Bacteriol 179, 4319-4327.

Dougherty, L. J., Brown, E. G. \& Gallon, J. R. (1996). Nitrogenasespecific proteolytic activity in the unicellular cyanobacterium Gloeothece. Biochem Soc Trans 24, $401 S$.

Du, C. \& Gallon, J. R. (1993). Modification of the Fe protein of the nitrogenase of Gloeothece (Nägeli) sp. ATCC 27152 during growth under alternating light and darkness. New Phytol 125, 121-129.

Du, C. \& Gallon, J. R. (1996). Degradation and modification of Feprotein of nitrogenase in cultures of Gloeothece grown under alternating light and darkness. Physiol Mol Biol Plants 2, 87-94.

Du, C., Reade, J. P. H., Rogers, L. J. \& Gallon, J. R. (1994). Dinitrogenase reductase ADP-ribosyl transferase and dinitrogenase reductase activating glycohydrolase in Gloeothece. Biochem Soc Trans 22, 332 S.

Durner, J. I. B., Knörzer, O. C. \& Böger, P. (1996). Proteolytic degradation of dinitrogenase reductase from Anabaena variabilis (ATCC 29413) as a consequence of ATP depletion and impact of oxygen. $J$ Bacteriol 178, 606-610.

Ernst, A., Liu, Y.-D., Reich, S. \& Böger, P. (1990). Diurnal nitrogenase modification in the cyanobacterium Anabaena variabilis. Bot Acta 103, 183-189.

Fay, P. (1992). Oxygen relations of nitrogen fixation in cyanobacteria. Microbiol Rev 56, 340-373.

Gallon, J. R. (1981). The oxygen sensitivity of nitrogenase: a problem for biochemists and microorganisms. Trends Biochem Sci 6, 19-23.

Gallon, J. R. (1992). Reconciling the incompatible: $\mathrm{N}_{2}$ fixation and $\mathrm{O}_{2}$. (Tansley review no. 44). New Pbytol 122, 571-609.

Gallon, J. R. \& Chaplin, A. E. (1988). Nitrogen fixation. In The Biochemistry of Algae and Cyanobacteria, pp. 147-173. Edited by L. J. Rogers \& J. R. Gallon. Oxford: Oxford University Press.

Gallon, J. R. \& Hamadi, A. F. (1984). Studies on the effects of oxygen on acetylene reduction (nitrogen fixation) in Gloeothece sp. ATCC 27152. J Gen Microbiol 130, 495-503.

Gallon, J. R., UI-Haque, M. I. \& Chaplin, A. E. (1978). Fluoroacetate metabolism in Gloeocapsa sp. LB795 and its relationship to acetylene reduction (nitrogen fixation). J Gen Microbiol 106, 329-336.

Gallon, J. R., Perry, S. M., Rajab, T. M. A., Flayeh, K. A. M., Yunes, J. S. \& Chaplin, A. E. (1988). Metabolic changes associated with the diurnal pattern of $\mathrm{N}_{2}$ fixation in Gloeothece. J Gen Microbiol 134, 3079-3087.

Gallon, J. R., Perry, S. M. \& Flynn, K. J. (1990). The immediate fate of $\mathrm{N}_{2}$ fixed by Gloeothece growing under alternating light and darkness. In Nitrogen Fixation: Achievements and Objectives, p. 534. Edited by P. M. Gresshoff, L. E. Roth, G. Stacey \& W. E. Newton. New York: Chapman \& Hall.

Gallon, J. R., Pederson, D. M. \& Smith, G. D. (1993). The effect of temperature on the sensitivity of nitrogenase to oxygen in the cyanobacteria Anabaena cylindrica (Lemmermann) and Gloeothece (Nägeli). New Phytol 124, 251-257.

Gallon, J. R., Reade, J. P. H., Dougherty, L. J., Pederson, D. M. \& Rogers, L. J. (1995). Degradation of nitrogenase in Gloeothece. In Nitrogen Fixation: Fundamentals and Applications, p. 230.
Edited by I. A. Tikhonovich, N. A. Provorov, V. I. Romanov \& W. E. Newton. Dordrecht: Kluwer.

Hamadi, A. F. \& Gallon, J. R. (1981). Calcium ions, oxygen and acetylene reduction (nitrogen fixation) in the unicellular cyanobacterium Gloeocapsa sp. 1430/3. J Gen Microbiol 125, 391-398.

Huang, T.-C. \& Chow, T.-J. (1988). Comparative studies of some nitrogen-fixing unicellular cyanobacteria isolated from rice fields. J Gen Microbiol 134, 3089-3097.

Kennedy, C., Eady, R. R., Kondorosi, E. \& Rekosh, D. K. (1976). The molybdenum-iron protein of Klebsiella pneumoniae nitrogenase: evidence for non-identical subunits from peptide 'mapping' Biochem J 155, 383-389.

Khamees, H. S., Gallon, J. R. \& Chaplin, A. E. (1987). The pattern of acetylene reduction by cyanobacteria grown under alternating light and darkness. Br Phycol J 22, 55-60.

Ludden, P. W., Roberts, G. P., Lowery, R. G. \& 9 other authors (1988). Regulation of nitrogenase activity by reversible ADPribosylation of dinitrogenase reductase. In Nitrogen Fixation: Hundred Years After, pp. 157-162. Edited by H. Bothe, F. J. de Bruijn \& W. E. Newton. Stuttgart: Fischer.

Maryan, P. S., Eady, R. R., Chaplin, A. E. \& Gallon, J. R. (1986). Nitrogen fixation by the unicellular cyanobacterium Gloeothece. Nitrogenase synthesis is only transiently repressed by $\mathrm{O}_{2}$. FEMS Microbiol Lett 34, 251-255.

Mazel, D., Gugliemi, G., Houmard, J., Sidler, W., Bryant, D. A. \& Tandeau de Marsac, N. (1986). Green light induces transcription of the phycoerythrin operon in the cyanobacterium Calotbrix 7601. Nucleic Acids Res 14, 8279-8290.

Mitsui, A. \& Suda, S. (1995). Alternative and cyclic appearance of $\mathrm{H}_{2}$ and $\mathrm{O}_{2}$ photoproduction activities under nongrowing conditions in an aerobic nitrogen-fixing unicellular cyanobacterium Synechococcus sp. Curr Microbiol 30, 1-6.

Mitsui, A., Kumazawa, S., Takahashi, A., Ikemoto, H., Cao, S. \& Arai, T. (1986). Strategy by which nitrogen-fixing unicellular cyanobacteria grow photoautotrophically. Nature 323, 720-722.

Mullineaux, P. M., Gallon, J. R. \& Chaplin, A. E. (1981). Acetylene reduction (nitrogen fixation) by cyanobacteria grown under alternating light-dark cycles. FEMS Microbiol Lett 10, 245-247.

Ohki, K., Zehr, J. P. \& Fujita, Y. (1992). Regulation of nitrogenase activity in relation to the light-dark regime in the filamentous non-heterocystous cyanobacterium Trichodesmium sp. NIBB 1067. J Gen Microbiol 138, 2679-2685.

Plantner, J. J. (1991). A microassay for proteolytic activity. Anal Biochem 195, 129-131.

Rumbeli, R., Suter, F., Wirth, M., Sidler, W. \& Zuber, H. (1987). Gamma-N-methyl asparagine in phycobiliproteins from the cyanobacteria Mastigocladus laminosus and Calothrix. FEBS Lett 221, 1-2.

Sidler, W. A. (1994). Phycobilisome and phycobiliprotein structure. In The Molecular Biology of Cyanobacteria, pp. 139-216. Edited by D. A. Bryant. Dordrecht : Kluwer.

Smith, B. E. \& Eady, R. R. (1992). Metalloclusters of the nitrogenases. Eur J Biochem 205, 1-15.

Stal, L. J. \& Bergman, B. (1990). Immunological characterization of nitrogenase in the filamentous cyanobacterium Oscillatoria limosa. Planta 182, 287-291.

Stal, L. J. \& Krumbein, W. E. (1985). Nitrogenase activity in the non-heterocystous cyanobacterium Oscillatoria sp. grown under alternating light-dark cycles. Arch Microbiol 143, 67-71.

Villbrandt, M., Stal, L. J., Bergman, B. \& Krumbein, W. E. (1992). Immunolocalization and Western blot analysis of nitrogenase in 
Oscillatoria limosa during a light-dark cycle. Bot Acta 105, 90-96.

Wyman, M., Gregory, R. P. F. \& Carr, N. G. (1985). Novel role for phycoerythrin in a marine cyanobacterium, Synechococcus strain DC2. Science 230, 818-820.

Wyman, M., Gregory, R. P. F. \& Carr, N. G. (1986). Role of phycoerythrin in marine picoplankton Synechococcus spp. response. Science 234, 1423-1424.
Zehr, J. P., Wyman, M., Miller, V., Duguay, L. \& Capone, D. G. (1993). Modification of the Fe protein of nitrogenase in natural populations of Trichodesmium thiebautii. Appl Environ Microbiol 59, 669-676.

Received 10 August 1998; revised 16 February 1999; accepted 26 March 1999. 